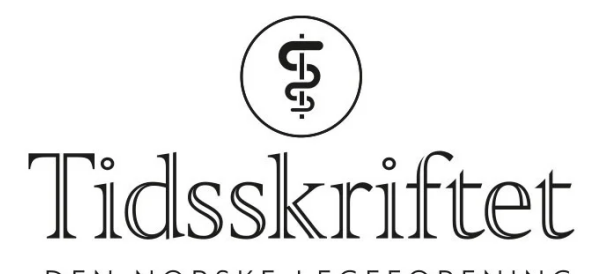

DEN NORSKE LEGEFORENING

\title{
Re: Profesjonalitet kommer ikke av seg selv
}

RETTELSE

EIVIND LIED

Tidsskr Nor Legeforen 2014; 134: 1634

I Tidsskriftet nr. 17/2014 side 1634 skal riktig fødselsår på forfatteren være 1988.

Vi beklager feilen, den er rettet i nettutgaven.

Publisert: 14. oktober 2014. Tidsskr Nor Legeforen. DOI: 10.4045/tidsskr.14.1144

(C) Tidsskrift for Den norske legeforening 2023. Lastet ned fra tidsskriftet.no 26. april 2023. 